УДК 330.3:656.2

\title{
ІНСТРУМЕНТАРІЙ ЗАБЕЗПЕЧЕННЯ ЗБАЛАНСОВАНОГО РОЗВИТКУ АТ «УКРЗАЛІЗНИЦЯ» В УМОВАХ РЕАЛІЗАЦІЇ ЦИФРОВИХ ЗМІН У ГАЛУЗІ
}

\author{
Овчиннікова В. О., д.е.н., професор, \\ Обруч Г. В., к.е.н., доцент, \\ Веселов А. М., магістр, \\ Гавриш К. В., магістр (УкрДУЗТ)
}

У статті досліджено наукові підходи до визначення $i$ систематизації інструментів забезпечення збалансованого розвитку підприємств, у т. ч. залізничного транспорту. Доведено необхідність удосконалення інструментарію забезпечення збалансованого зростання АТ «Укрзалізниця» з урахуванням глобальних трендів циифрової перебудови середовища його функціонування. Розкрито кониепиію забезпечення збалансованого розвитку АT «Укрзалізниця», у межах якої визначено стратегічну мету, тактичні иілі та завдання забезпечення сталого зростання підприємств галузі. Сформовано систему сиенаріїв забезпечення збалансованого розвитку АТ «Укрзалізниця», яка розкриває інструменти забезпечення його сталого зростання залежно від міри проникнення цифррових технологій у галузь. Доведено, що практичне впровадження конщепиї та системи сиенарїв забезпечення збалансованого зростання залізничного транспорту дозволить трунтовно підійти до вибору стратегіі та інструментів реалізації цииррових змін у галузі.

Ключові слова: збалансований розвиток, підприємства залізничного транспорту, цифровізація, концепція, система сценарї̈, інструменти.

\section{ИНСТРУМЕНТАРИЙ ОБЕСПЕЧЕНИЯ СБАЛАНСИРОВАННОГО РАЗВИТИЯ АО «УКРЗАЛИЗНЫЦЯ» В УСЛОВИЯХ РЕАЛИЗАЦИИ ЦИФРОВЫХ ИЗМЕНЕНИЙ В ОТРАСЛИ}

\author{
Овчинникова В. А., о.э.н., профессор, \\ Обруч А. В., к.э.н., доцент, \\ Веселов А. Н., магистр, \\ Гавриш Е. В., магистр (УкрГУЖТ)
}

В статье исследованы научные подходы $к$ определению и систематизачии инструментов обеспечения сбалансированного развития предприятий, в частности железнодорожного транспорта. Доказана необходимость совершенствования инструментария обеспечения сбалансированного развития $A O$ «Укрзализныця» $c$ учетом глобальных трендов циифровой трансформации среды его функционирования. Раскрыта концепџия обеспечения устойчивого развития $A O$ «Укрзализныця», в рамках которой определена стратегическая цель, тактические цели и задачи обеспечения устойчивого роста предприятий отрасли. Сформирована система сценариев обеспечения сбалансированного развития $А O$ «Укрзализныия», которая раскрывает инструменты обеспечения его устойчивого роста в зависимости от степени проникновения ичифровых технологий в отрасль. Доказано, что практическое (с) Овчиннікова В. О.,

Вісник економіки транспорту і промисловості № 70-71, 2020 Обруч Г. В., 
внедрение кониепции и системы сценариев обеспечения сбалансированного развития железнодорожного транспорта позволит основательно подойти к выбору стратегии и инструментов реализации цฺифровых изменений в отрасли.

Ключевые слова: сбалансированное развитие, предприятия железнодорожного транспорта, цифровизация, концепция, система сценариев, инструменты.

\title{
TOOLS FOR ENSURING THE BALANCED DEVELOPMENT OF JSC "UKRAINIAN RAILWAYS" IN THE CONTEXT OF IMPLEMENTING DIGITAL CHANGES IN THE INDUSTRY
}

\author{
Ovchynnikova V. O., Doctor of Economics, Professor, \\ Obruch H. V., Candidate of Economics, Associate professor, \\ Veselov A. M., master's degree, \\ Gavrish K. V., master's degree (USURT)
}

The article examines scientific approaches to the definition and systematization of tools for balanced development of enterprises, including railway transport. The necessity of improving the tools for ensuring balanced growth of JSC "Ukrainian Railways", taking into account global trends in digital restructuring of their operating environment, is proved. Examples of successful international experience in implementing digital modernization projects of railway transport enterprises are studied. The concept of ensuring balanced development of JSC "Ukrainian Railways" is revealed, within the framework of which the strategic goal, goals and objectives of ensuring sustainable growth of industry enterprises are defined. The peculiarity of the concept is that the goals of balanced growth of railway transport enterprises are reflected, firstly, in the context of the augmented real and virtual environment of their development in accordance with the economic, environmental and social motives for the growth of industry enterprises, and, secondly, in the areas of ensuring balanced growth of railway transport enterprises in the context of digital transformations in the industry. A system of scenarios for ensuring the balanced development of JSC "Ukrainian Railways" (inertial, fragmentary-adaptive, progressive-adaptive, coevolutionary-digital) is formed and tools for ensuring their sustainable growth are revealed depending on the degree of penetration of digital technologies into the industry and the desired level of balanced development of railway transport enterprises. Taking into account the expediency of ensuring an absolute balance of railway transport enterprises in order to form stable competitive positions in the market of transport and logistics services, it is indicated that it is advisable to use a coevolutionary digital scenario. Since the use of tools for this scenario of balanced development of railway transport enterprises will allow us to fully implement digital changes in the qualitative transformation of services, innovation and investment processes, and the formation of digital competencies of personnel of industry enterprises.

Keywords: balanced development, railway transport enterprises, digitalization, concept, scenario system, tools.

Постановка проблеми. В умовах поглиблення глобальних соціальних та екологічних деструктив разом 3 економічною ефективністю діяльності бізнес-суб' єктів позиціонується важливість урахування таких домінант розвитку, як забезпечення соціальної стабільності та досягнення екологічної рівноваги, що в сукупності формують основу концепції збалансованого господарювання. Попри задекларованість принципів сталого розвитку вітчизняних підприємств на

Вісник економіки транспорту і промисловості № 70-71, 2020 
державному рівні, слід вказати на те, що наразі відсутне комплексне бачення збалансованого зростання підприємств базових галузей економіки, зокрема залізничного транспорту. Незважаючи на відображення принципів сталого господарювання в стратегії розвитку АТ «Укрзалізниця», ці принципи не знайшли належного практичного втілення, i повноцінно не використовуються цифрові інструменти забезпечення збалансованого зростання підприємств галузі, ефективність застосування яких неодноразово була підтверджена в процесі використання світовими компаніями. 3 огляду на це, важливого значення набуває розроблення інструментарію забезпечення збалансованого розвитку

AT «Укрзалізниця» 3 урахуванням світового досвіду реалізації ініціатив сталого зростання залізничними компаніями. Оскільки використання такого роду інструментарію в практичній діяльності вітчизняних підприємств залізничного транспорту дозволить нівелювати дисбаланси їх діяльності і реалізувати цифровий потенціал зростання підприємств галузі.

Аналіз останніх досліджень $i$ публікацій. У працях вітчизняних вчених приділяється вагома увага питанню забезпечення сталого зростання бізнессуб'єктів, у т.ч. і підприємств залізничного транспорту. Цій проблематиці присвятили свої публікації такі вчені-дослідники, як В. Дикань, М. Звєряков, Н. Каличева, М. Корінь, Л. Кривенко, В. Овчиннікова, I. Токмакова та ін. [1-12]. Зокрема наукові праці [11-12] присвячено дослідженню сучасних інструментів збалансованого розвитку підприємств залізничного транспорту в аспекті їх цифровізації. Віддаючи належне здобуткам науковців, слід зазначити, що в умовах трансформації середовища функціонування i реалізації ініціатив цифрової модернізації АТ «Укрзалізниця» доцільним $€$ розроблення такого інструментарію забезпечення його збалансованого зростання, який міститиме як традиційні, так і цифрові інструменти розвитку підприємств галузі.

Метою наукової статmі $\epsilon$ формування інструментарію забезпечення збалансованого зростання АТ «Укрзалізниця» 3 урахуванням глобальних трендів цифрової перебудови середовища його функціонування.

Виклад основного матеріалу. Наразі в науковому колі сформувалася низка підходів до класифікації та систематизації інструментів збалансованого розвитку соціальноекономічних систем, у т. ч. підприємств залізничного транспорту. У роботі [8] автором визначено чотири основні групи інструментів:

адміністративні/регламентуючі;

економічні; соціальної мотивації; організаційні. Автори монографії [4] виділяють методи управління збалансованим розвитком територіальної соціально-економічної системи за функціональним призначенням i об'єднують їх у такі групи: адміністративні, бюджетні, податкові, грошово-кредитні. Л. Кривенко [7] адміністративно-контрольні, правові та економічні інструменти доповнює групою соціальних важелів, які, на думку автора, можуть бути представлені інструментами морально-етичного впливу й переконання, до яких відносяться: освіта і виховання, доступність інформації, суспільний тиск, переговорні процеси й добровільні екологічні погодження. Д. Гузь [1] як найбільш вагомі інструменти забезпечення стійкого розвитку підприємств виділяє такі: ефективна система економічної безпеки; інформаційне та фінансове забезпечення; інноваційна, інвестиційна та маркетингова політика. При цьому автором зосереджено увагу насамперед на доцільності застосування такого інструменту, як економічна безпека, що обумовлено його роллю в забезпеченні високого рівня захищеності діяльності підприємства від ризиків зовнішнього середовища, що підвищує ефективність дії інших інструментів i покращує умови для стійкого розвитку.

Вісник економіки транспорту і промисловості № 70-71, 2020 
У науковій праці [9] представлено систематизацію інструментів державного регулювання розвитку залізничного транспорту, яка враховує орієнтири розвитку галузі, i передбачає групування інструментів державної підтримки процесів формування стратегічних переваг за такими складовими розвитку залізничного транспорту, як інноваційна, інвестиційна, енергетична, екологічна, соціальна та міжнародна. Як першочергові напрями діяльності підприємств залізничного транспорту, що стануть базисом для економічного зростання за рахунок використання цифрових технологій, вченими виділено такі основні з них [11]: 1) розвиток клієнтського сервісу на основі використання цифрових комунікаційних каналів; 2) зміцнення партнерських відносин на базі цифрових платформ; 3) побудова прогнозів на основі Big Data; 4) реалізація кадрових стратегій, які полягають в постійному підвищенні кваліфікації працівників щодо формування компетенцій під потреби цифровізації галузі.

Отже, відзначаючи високий рівень наукових розробок щодо формування інструментарію забезпечення сталого розвитку підприємств залізничного транспорту, у т.ч. в аспекті їх цифровізації, слід вказати на те, що не знайшли належного відображення інструменти цифрової трансформації підприємств залізничної галузі як базису досягнення збалансованості їхньої діяльності, які активно використовуються у світовій практиці розвитку залізничних компаній.

Як свідчить світовий досвід, наразі цифрові технології розглядаються як дієвий інструмент досягнення як економічних, так і соціальних та екологічних цілей розвитку залізничного транспорту. Найбільш масштабними на сьогодні $\epsilon$ інфраструктурні проєкти розбудови транспортно-логістичної інфраструктури, обладнаної цифровими технологіями. Прискореними темпами відбувається розбудова цифровізованих високошвидкісних ліній, транспортних коридорів і транспортно-логістичних хабів. Відтак наразі вже введена в експлуатацію перша у світі автоматизована високошвидкісна залізниця, що з'єднала Пекін i місто Чжанцзякоу. Завдяки використанню рухомого складу, оснащеного мобільним зв'язком 5G, бездротовими зарядними пристроями та «розумним» освітленням, що досягає максимальної швидкості руху в 350 км/год, вдалося скоротити час поїздки 3 понад 3 год до 47 хв [13]. Крім того, у Пекіні ведуться роботи щодо будівництва підземних транспортно-логістичних хабів, що створять можливості для пересадки пасажирів між поїздами метро і залізниць.

Також залізничними компаніями реалізується низка соціальних проєктів, спрямованих на підвищення професійних якостей працівників і активізацію їхніх інтелектуальних здібностей, залучення та адаптацію нових співробітників, забезпечення соціальної захищеності працівників. Так, наприклад, Deutsche Bahn (Німеччина) у 2019 р. залучено близько 24 тис. нових працівників, у т. ч. машиністів, провідників, фахівців 3 електроніки та інформаційних технологій. Зокрема в концерні створено новий рекрутинговий відділ, що займається пошуком і наймом фахівців за межами Німеччини, зокрема в Іспанії, Італії, Греції, Північній Македонії, Сербіiі та Румунії. На 2020 p. Deutsche Bahn заплановано інвестиції в навчання співробітників у розмірі близько 500 млн євро. При цьому велика увага приділяється i створенню навчальних програм для підготовки персоналу до переходу на цифрові технології. Такі програми створені зокрема i для традиційних залізничних спеціальностей: чергових по станції, машиністів i провідників [14].

Викликають зацікавлення проєкти модернізації залізничного транспорту, розроблені 3 урахуванням екологічних цілей його розвитку. Так, у Німеччині у 2018 р. відбувся запуск потяга Coradia iLint на водневих паливних елементах, у процесі руху якого здійснюються викиди в

Вісник економіки транспорту і промисловості № 70-71, 2020 
навколишнє середовище лише у вигляді води та пару. Перші два потяги на водневому паливі 3 вересня 2018 p. експлуатуються в Нижній Саксонії. Місцева транспортна адміністрація LNVG планує 32021 р. організувати рух 14 таких поїздів. Транспортне об'єднання регіону Рейн-Майн RMV (Німеччина) замовило в компанії Alstom 27 поїздів Coradia iLint, що дозволить мати найбільший у світі парк рухомого складу на водневому паливі. До реалізації цієї ініціативи поступово долучаються й інші країни. Зокрема в Нідерландах наприкінці вересня 2020 р. відбулося успішне випробування водневого поїзда Coradia iLint, що дозволило дійти висновку про ефективність заміни дизельпоїздів на неелектрифікованих лініях рухомим складом 3 водневими паливними елементами. Після Німеччини Нідерланди стали другою країною в Європі, де водневий поїзд Alstom зарекомендував себе як унікальне рішення для неелектрифікованих ліній [15].

Дирекцією залізниць Норвегії (Jernbanedirektoratet) на основі дослідження можливостей відмови від використання дизельної тяги на неелектрифікованих лініях 3 метою повного виключення викидів вуглекислого газу вказано на п'ять альтернативних рішень: водневе паливо, біогаз, біодизель і тягові акумуляторні батареї - з частковою електрифікацією лінії або за іiі повної відсутності. За результатами дослідження зроблено висновок про найбільш ефективне використання рухомого складу з тяговими акумуляторними батареями в поєднанні 3 частковою електрифікацією. Ця технологія визнана найбільш надійною, крім того, вона сумісна 3 наявною інфраструктурою: поїзди 3 тяговими акумуляторними батареями можуть рухатися по всій залізничній мережі Норвегії. Загалом планується скоротити викиди вуглекислого газу в атмосферу на $45 \%$ до 2030 p. Ефективність використання таких дизельпоїздів визнано i Німеччиною, що заключила контракт з компанією Alstom на виготовлення і поставку 11 електропоїздів
Coradia Continental, розрахованих на живлення як від контактної мережі, так і акумуляторних батарей [16].

Вивчення сучасного стану підприємств залізничного транспорту України i особливостей впровадження цифрових технологій у галузі дозволило дійти висновку про поступову втрату стабілізаційних здатностей АТ «Укрзалізниця» i обмеженість наявних можливостей щодо забезпечення його цифрової трансформації і модернізації. Виникнення такого роду негативних тенденцій зумовлено як погіршенням технічної та технологічної оснащеності підприємств галузі і відповідно якості транспортно-логістичного обслуговування, так i зниженням інвестиційного та кредитного рейтингів АТ «Укрзалізниця» $\mathrm{i}$ рівня кадрового забезпечення його діяльності. Все це вказує на невизначеність цілей та інструментів цифрової модернізації послуг, інвестиційних та інноваційних процесів i компетенцій персоналу АТ «Укрзалізниця» і відповідно зумовлює потребу комплексного застосування сучасних цифрових рішень у сфері залізничного транспорту як базису забезпечення збалансованого розвитку підприємств галузі. 3 огляду на особливості середовища функціонування підприємств залізничного транспорту i потребу гармонізації різновекторних цілей їх діяльності, доцільним $\epsilon$ розроблення концепції забезпечення збалансованого зростання АТ «Укрзалізниця», в основу якої слід покласти принцип полікритеріальної узгодженості цілей його сталого зростання (рис. 1). Останній реалізується завдяки відображенню цілей у розрізі доповненого реального $\mathrm{i}$ віртуального середовища розвитку АТ «Укрзалізниця» відповідно до економічних, екологічних та соціальних мотивів його зростання, а також за напрямами забезпечення збалансованого розвитку підприємств залізничного транспорту в умовах реалізації цифрових перетворень у галузі.

Вісник економіки транспорту і промисловості № 70-71, 2020 


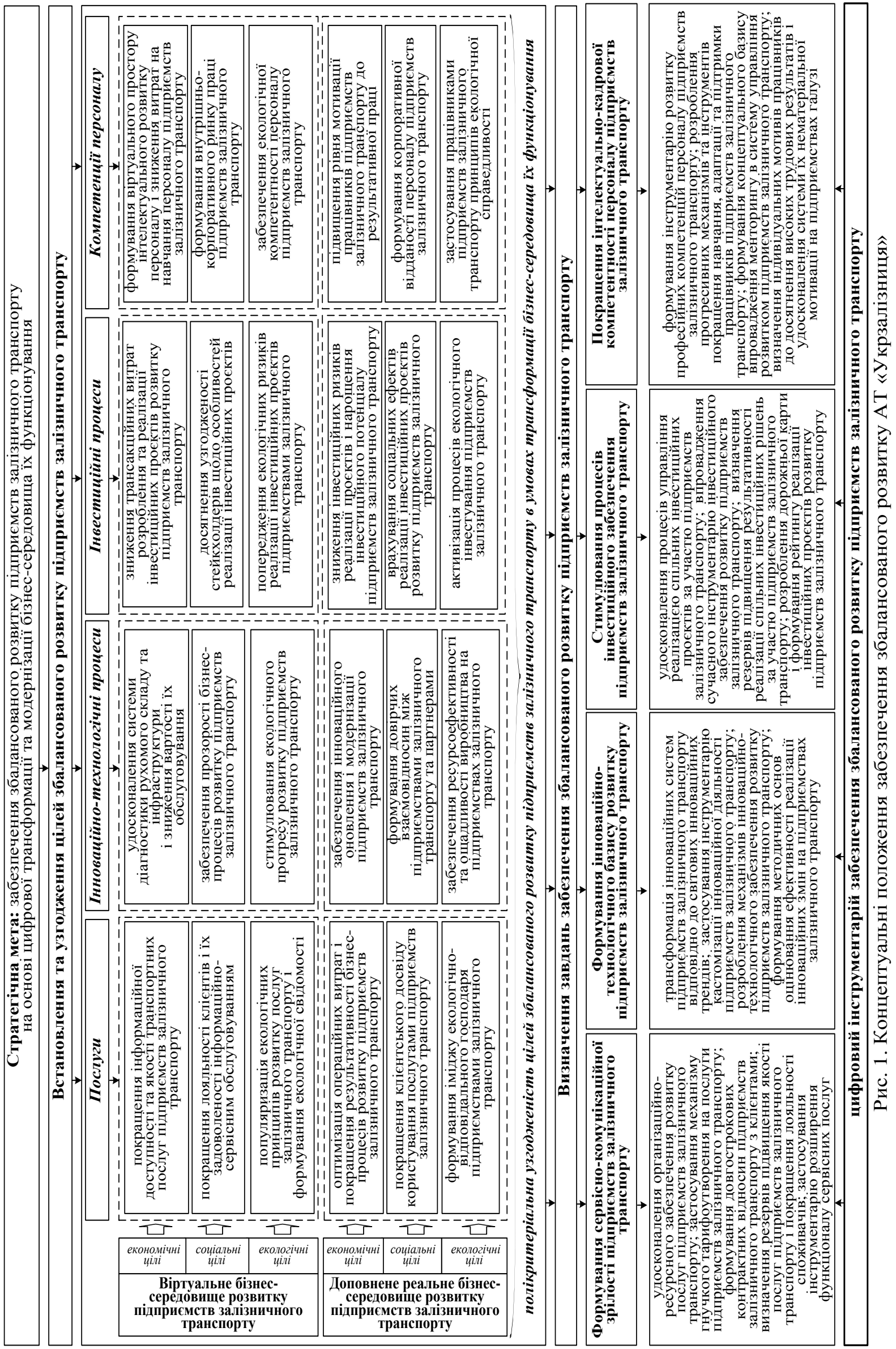

Вісник економіки транспорту і промисловості № 70-71, 2020 
Слід зазначити, що досягнення цілей збалансованого зростання АТ «Укрзалізниця» потребує вирішення низки важливих завдань:

1) формування сервіснокомунікаційної зрілості АТ «Укрзалізниця», що грунтується на удосконаленні організаційно-ресурсного забезпечення розвитку послуг підприємств залізничного транспорту; застосуванні механізму гнучкого тарифоутворення на послуги підприємств залізничного транспорту; формуванні довгострокових контрактних відносин підприємств залізничного транспорту 3 клієнтами; визначенні резервів підвищення якості послуг підприємств залізничного транспорту i покращенні лояльності споживачів; застосуванні інструментарію розширення функціоналу сервісних послуг тощо;

2) формування інноваційнотехнологічного базису розвитку АТ «Укрзалізниця» за рахунок трансформації інноваційних систем підприємств залізничного транспорту відповідно до світових інноваційних трендів; застосування інструментарію кастомізації інноваційної діяльності підприємств залізничного транспорту; розроблення механізмів інноваційнотехнологічного забезпечення розвитку підприємств залізничного транспорту; формування методичних основ оцінювання ефективності реалізації інноваційних змін на підприємствах залізничного транспорту тощо;

3) стимулювання процесів інвестиційного забезпечення АТ «Укрзалізниця», що потребує удосконалення процесів управління реалізацією спільних інвестиційних проєктів за участю підприємств залізничного транспорту; впровадження сучасного інструментарію інвестиційного забезпечення розвитку підприємств залізничного транспорту; визначення резервів підвищення результативності реалізації спільних інвестиційних рішень за участю підприємств залізничного транспорту; розроблення дорожньої карти i формування рейтингу реалізації інвестиційних проєктів розвитку підприємств залізничного транспорту тощо;

4) покращення інтелектуальнокадрового забезпечення АТ «Укрзалізниця», що пов’язано 3 формуванням інструментарію розвитку професійних компетенцій персоналу підприємств залізничного транспорту; розробленням прогресивних механізмів та інструментів покращення навчання, адаптації та підтримки працівників підприємств залізничного транспорту; формуванням концептуального базису впровадження менторингу в систему управління розвитком підприємств залізничного транспорту; визначенням індивідуальних мотивів працівників до досягнення високих трудових результатів i удосконаленням системи їx нематеріальної мотивації тощо.

Ефективність реалізації визначених завдань забезпечення збалансованого розвитку АТ «Укрзалізниця» у значній мірі залежить від дієвості застосовуваного інструментарію i його відповідності глобальним трендам модернізації залізничної галузі. Для успішного вибору цифрових інструментів забезпечення збалансованого зростання підприємств залізничного транспорту доцільним $\epsilon$ застосування системи сценаріїв, що в якості критерію вибору інструментів визначає міру проникнення цифрових технологій у діяльність підприємств галузі (інерційний, фрагментарноадаптивний, прогресивно-адаптивний, коеволюційно-цифровий). Вибір сценарію, у свою чергу, залежить від поточного рівня та бажаного стану збалансованості цілей та інструментарію сталого зростання АТ «Укрзалізниця». Відтак збереження досягнутого рівня збалансованості розвитку підприємств залізничного транспорту передбачає застосування інерційного сценарію, що зорієнтований на ситуативне впровадження доступних технологічних

Вісник економіки транспорту і промисловості № 70-71, 2020 
рішень у діяльність підприємств галузі. Досягнення задовільного рівня збалансованості розвитку підприємств залізничного транспорту потребує застосування фрагментарно-адаптивного сценарію, що відповідно передбачає фрагментарне впровадження сучасних технологічних рішень, спрямованих на вирішення окремих проблем розвитку підприємств галузі. Прогресивноадаптивний сценарій забезпечення збалансованого розвитку підприємств залізничного транспорту, що передбачає впровадження технологічних рішень у діяльність підприємств галузі 3 метою стабілізації їх діяльності, доцільно використовувати у випадку досягнення достатнього рівня збалансованості. Коеволюційно-цифровий сценарій забезпечення збалансованого розвитку підприємств залізничного транспорту передбачає впровадження новітніх комплексних та локальних цифрових рішень залежно від пріоритетів розвитку підприємств галузі і потреби забезпечення ïх цифрової когерентності. Його практичне впровадження надасть змогу досягти абсолютної збалансованості розвитку підприємств залізничного транспорту.

3 огляду на доцільність забезпечення абсолютної збалансованості розвитку АТ «Укрзалізниця» 3 метою формування стійких конкурентних позицій на ринку транспортних послуг потребує застосування коеволюційноцифровий сценарій. Оскільки практичне застосування інструментів зазначеного сценарію дозволить повноцінно реалізувати цифрові зміни щодо якісної трансформації послуг, інноваційних та інвестиційних процесів і формування цифрових компетенцій персоналу АТ «Укрзалізниця».

Зокрема

збалансованого розвитку послуг підприємств залізничного транспорту передбачає застосування таких інструментів як цифрові транспортнологістичні коридори за участю підприємств залізничного транспорту, цифрові платформи розвитку вантажних і пасажирських перевезень i управління активами підприємств галузі, механізми інтерактивної взаємодії зі стейкхолдерами 3 урахування їх потреб, цифрові сервіси аналізу потреб клієнтів, система організаційно-ресурсного забезпечення цифрових змін тощо. Активізація процесів інноваційно-технологічного розвитку підприємств залізничного транспорту потребує впровадження таких інструментів як моделі відкритих інновацій за участю підприємств залізничної галузі, новітні рішення діагностики та управління рухомим складом, інтелектуальні карти залізничної мережі і цифрові рішення іiі діагностики, цифрові лабораторії і виробництва для потреб підприємств залізничного транспорту, цифрові платформи інноваційно-технологічного

співробітництва підприємств галузі тощо. Стимулювання процесів інвестиційного забезпечення збалансованого розвитку підприємств залізничного транспорту стає можливим завдяки використанню таких інструментів як механізм управління реалізацією спільних інвестиційних проектів за участю підприємств галузі, проактивне управління реалізацією спільних інвестиційних проектів за участю підприємств залізничного транспорту, методичне забезпечення оцінювання пріоритетності інвестування бізнес-сегментів розвитку підприємств галузі, корпоративні венчурні фонди інвестування стартап-проєктів на підприємствах залізничного транспорту тощо. Розвиток компетенцій персоналу як базису інтелектуально-кадрового забезпечення збалансованого зростання підприємств залізничного транспорту передбачає застосування таких інструментів як програми формування i розвитку цифрових компетенцій персоналу підприємств галузі, цифрові платформи управління персоналом підприємств залізничного транспорту, системи нематеріальної мотивації

Вісник економіки транспорту і промисловості № 70-71, 2020 
персоналу підприємств галузі 3 урахуванням їх домінуючих цінностей i потреб, цифрові інструменти управління адаптацією персоналу підприємств залізничного транспорту, зокрема менторинг, тощо.

\section{Висновки.}

Таким

чином, розроблено концепцію забезпечення збалансованого розвитку

АТ «Укрзалізниця», в межах якої розкрито стратегічну мету, основні цілі та завдання забезпечення сталого зростання підприємств галузі. Визначено сценарії забезпечення збалансованого розвитку підприємств залізничного транспорту, що розкривають інструменти забезпечення їх сталого зростання залежно від міри проникнення цифрових технологій у галузь $\mathrm{i}$ запланованого рівня збалансованості розвитку АТ «Укрзалізниця». Зазначено, що практичне втілення концепції та системи сценаріїв забезпечення збалансованого зростання АТ «Укрзалізниця» дозволить грунтовно підійти до вибору стратегіï та інструментів реалізації цифрових змін у галузі.

\section{ПЕРЕЛІК ВИКОРИСТАНИХ ДЖЕРЕЛ}

1 Гузь Д. О. Формування стратегії забезпечення стійкого економічного розвитку підприємств туристичної сфери : дис. ... канд. екон. наук : 08.00 .04 / Одеський національний університет імені I. І. Мечникова. Одеса, 2018. 217 с.

2 Дикань В. Л. Комплексний підхід до управління стійким розвитком підприємств машинобудування. Вісник економіки транспорту $і$ промисловості. 2015. № 49. С. $11-18$.

3 Дикань В.Л., Соломніков І.В. Інжиніринго-маркетинговий центр інноваційних технологій як основа активізації інноваційно-інвестиційного потенціалу підприємств залізничного транспорту. Вісник економіки транспорту і промисловості. 2017. Вип. 57. С. 9-20.

4 Звєряков M.I., Ковальов А.I., Сментина Н.В. Стратегічне планування збалансованого розвитку територіальних соціально-економічних систем в умовах децентралізації: монографія. Одеса: OHEУ, 2017. 175 c.

5 Каличева Н.Є. Концептуальні положення управління екологоекономічним розвитком підприємств залізничного транспорту. Науковий вісник міжнародного гуманітарного університету. Серія: Економіка $i$ менеджмент. 2020. Вип. 43. С. 110-113.

6 Корінь М.В. Розвиток інфраструктури залізничного транспорту в умовах транскордонного співробітництва: монографія. Харків: УкрДУЗТ, 2019. 401 с.

7 Кривенко Л. В. Соціальноекономічні інструменти забезпечення сталого розвитку. Механізм регулювання економіки. 2011. № 2. С. 33-37.

8 Половян А. В. Типология инструментария сбалансированного развития экономических систем. Вісник Донбаської державної машинобудівної академії. 2012. № 1 (26). С. 196-201.

9 Токмакова І. В., Овчиннікова В. О., Корінь М. В. Напрямки та інструменти державного регулювання стратегічного розвитку залізничного транспорту. Вісник економіки транспорту $і$ промисловості. 2020. Вип. 69. С. 114-127.

10 Токмакова I. В. Забезпечення гармонійного розвитку залізничного транспорту України: монографія. Харків: УкрДУЗТ, 2015. 403 с.

11 Овчиннікова В.О., Торопова В.І. Розвиток підприємств залізничного транспорту України в умовах цифровізації. Вісник економіки транспорту і промисловості. 2019. № 68. C. 175-181.

12 Токмакова I. В., Чередниченко О. Ю., Войтов І. М., Паламарчук Я.С. Цифрова трансформація залізничного транспорту як фактор його інноваційного розвитку. Вісник економіки транспорту $i$ промисловості. 2019. № 68. С. 125-134.

13 В Китае открыта первая в мире автоматизированная ВСМ, связывающая города проведения игр зимней

Вісник економіки транспорту і промисловості № 70-71, 2020 
Олимпиады 2022. Железные дороги мира : веб-сайт. URL

http://www.zdmira.com/news/vpekinestroitsa krupne

jsijvaziipodzemnyjtransportno-

peresadocnyjuzel (дата обращения: 05.10.2020)

14 Железные дороги Германии увеличивают штат и вкладывают 500 млн евро в обучение сотрудников. Железные дороги мира : веб-сайт. URL : http://www.zdmira.com/news/zeleznyedorogi germaniiuvelicivautstativkladyvaut $500 \mathrm{mlnev}$ rovobuceniesotrudnikov (дата обращения: 08.10.2020).

15 В Голландії успішно випробуваний водневий поїзд. Главком: веб-сайт.

URL

https://glavcom.ua/new_energy/news/vgollandiji-uspishno-viprobuvaniy-vodneviypojizd-708653.html (дата звернення: 12.10.2020).

16 В Норвегии выбрали тяговые аккумуляторные батареи на замену дизельной тяге. Железные дороги мира : веб-сайm.

URL

http://www.zdmira.com/news/vnorvegiivybra litagovyeakkumulatornyebatareinazamenudiz elnojtage (дата обращения: 15.10.2020).

\section{REFERENCES}

1 Huz, D. O. Formuvannia stratehii zabezpechennia stiikoho ekonomichnoho rozvytku pidpryiemstv turystychnoi sfery [Formation of a strategy for ensuring sustainable economic development of tourism enterprises], Doctor's Thesis, Economics and business management. Kharkiv: Ukrainian State University of Railway Transport, 2019.

2 Dykan V.L. (2015) Kompleksnyj pidkhid do upravlinnia stijkym rozvytkom pidpryiemstv mashynobuduvannia [Integrated approach to managing the sustainable development of mechanical engineering enterprises], Bulletin of the Economics of Transport and Industry, vol. 49. pp. 11-18.

3 Dykan V.L., Solomnikov I.V.
(2017) Inzhynirynho-marketynhovyy tsentr innovatsiynykh tekhnolohiy yak osnova aktyvizatsiyi innovatsiyno-investytsiynoho potentsialu pidpryyemstv zaliznychnoho transportu [Engineering and marketing center of innovative technologies as a basis for activation of innovation and investment potential of railway enterprises], Bulletin of Economics of Transport and Industry, vol. 57, pp. 9-20.

4 Zvieriakov M.I., Kovalov, A.I. and Smentyna, N.V. Stratehichne planuvannia zbalansovanoho rozvytku terytorialnykh sotsialno-ekonomichnykh system $\mathrm{v}$ umovakh detsentralizatsii [Strategic planning of balanced development of territorial socioeconomic systems in conditions of decentralization]. Odesa: ONEU, 2017.

$$
5 \text { Kalycheva N.Ye. }
$$

Kontseptualni polozhennia upravlinnia ekoloho-ekonomichnym rozvytkom pidpryiemstv zaliznychnoho transportu [Conceptual provisions of the management of ecological and economic development of railway transport enterprises], Scientific Bulletin of the International Humanitarian University. Series: Economics and management, vol. 43. pp. 110-113.

6 Korin' M.V. Rozvytok infrastruktury zaliznychnoho transportu $\mathrm{V}$ umovakh transkordonnoho spivrobitnytstva [Development of railway transport infrastructure in the context of cross-border cooperation]. Kharkiv: USURT, 2019.

7 Kryvenko L.V. (2011) Sotsialnoekonomichni instrumenty zabezpechennia staloho rozvytku [Socio-economic instruments for sustainable development], Mechanism for regulating the economy, vol. 2, pp. 33-37.

8 Polovian A.V. (2012) Tipologiya instrumentariya sbalansirovannogo razvitiya ekonomicheskikh sistem [Typology of tools for balanced development of economic systems], Bulletin of the Donbass State Machine-Building Academy, vol. 1, pp. 196201.

9 Tokmakova I.V., Ovchynnikova V. O. and Korin' M.V. (2020) Napriamky ta instrumenty derzhavnoho rehuliuvannia

Вісник економіки транспорту і промисловості № 70-71, 2020 
stratehichnoho rozvytku zaliznychnoho transportu [Directions and tools of state regulation of strategic development of railway transport]. Bulletin of Economics of Transport and Industry, vol. 69, pp. 114-127.

10 Tokmakova I.V. Zabezpechennia harmonijnoho rozvytku zaliznychnoho transportu Ukrainy [Ensuring the harmonious development of railway transport in Ukraine]. Kharkiv: USURT, 2015.

11 Ovchynnikova V.A., Toropova V.I. (2019) Rozvytok pidpryyemstv zaliznychnoho transportu Ukrayiny $\mathrm{v}$ umovakh tsyfrovizatsiyi [Development of railway enterprises of Ukraine in the conditions of digitalization]. Bulletin of Economics of Transport and Industry, vol. 68, pp. 175-181.

12 Tokmakova I.V., Cherednichenko O.J., Voitov I.M., Palamarchuk Y.S. (2019) Tsyfrova transformatsiya zaliznychnoho transportu yak faktor yoho innovatsiynoho rozvytku [Digital transformation of railway transport as a factor of its innovative development]. Bulletin of Economics of Transport and Industry, vol. 68, pp. 125-134.

13 Railways of the world: website
(2019), China has opened the world's first automated HSR connecting the host cities of the 2022 winter Olympics, available at: http://www.zdmira.com/news/vpekinestroitsa krupnejsijvaziipodzemnyjtransportnoperesadocnyjuzel (Accessed 5 Oct 2020).

14 Railways of the world: website (2019), German Railways increase staff and invest 500 million euros in employee training, available at: http://www.zdmira.com/news/zeleznyedorogi germaniiuvelicivautstativkladyvaut $500 \mathrm{mlnev}$ rovobuceniesotrudnikov (Accessed 8 Oct 2020).

15 glavcom.ua: website (2020), Hydrogen train successfully tested in Holland, available at: https://glavcom.ua/new_energy/news/vgollandiji-uspishno-viprobuvaniy-vodneviypojizd-708653.html (Accessed 12 Oct 2020). 16 Railways of the world: website (2020), In Norway, traction batteries were chosen to replace diesel traction, available at: http://www.zdmira.com/news/vnorvegiivybra litagovyeakkumulatornyebatareinazamenudiz elnojtage (Accessed 15 Oct 2020). 